\title{
AN ASSESSMENT OF USING ANAEROBIC BAFFLED REACTOR TO UPGRADE WASTEWATER STABILIZATION PONDS: A PILOT STUDY
}

\author{
SH. JAMSHIDI ${ }^{1} \&$ G. BADALIANS GHOLIKANDI ${ }^{2}$ \\ ${ }^{1}$ Water and Wastewater Research Center (WWRC), Water Research Institute (WRI), Tehran, Iran. \\ ${ }^{2}$ Department of Water and Wastewater, Power and Water University of Technology (PWUT), Iran.
}

\begin{abstract}
Operating wastewater treatment facilities is a challenge in developing countries. A research to find more sustainable alternatives is required with emphasize on modification, upgrade and optimization of these systems. Accordingly, a case study over a wastewater stabilization pond (WSP) of Hoveizeh, Iran, is carried out. It is realized that the facultative ponds have been encountered high purple sulfur bacteria (PSBs) bloom as a consequence of high organic loads. In fact, the overall efficiency of $70 \%$ in soluble COD removal is barely achieved in the system. This is recognized that volatile fatty acids (VFAs) have been motivated to be accumulated to more than $190 \mathrm{mg} / \mathrm{L}$ within the anaerobic ponds by high organic load. Hence, the ratio of VFAs to alkalinity is exceeded 0.6 and $\mathrm{H}_{2} \mathrm{~S}$ concentration is increased in the facultative pond. It is observed that the influent COD is correlated logarithmically to the $\mathrm{H}_{2} \mathrm{~S}$ concentration $\left(\mathrm{R}^{2}=0.9\right)$ and the latter itself is correlated in third order to the chlorophyll A $\left(\mathrm{R}^{2}=0.92\right)$ representing PSBs growth. Since this phenomenon is attributed to the accumulation of VFAs, it is recommended to use anaerobic baffled reactor (ABR) as a modification to control the process.

For this purpose, a bench-scale ABR with 481 volume and six compartments were fed with domestic wastewater and operated for 7 months in three hydraulic retention times (HRT) of 36, 24 and 18 hours. It is observed that the efficiency of soluble COD removal in the anaerobic part can be promoted from $45 \%$ to $70 \%$ by ABR with 24-h retention time while the effluent of COD and VFAs are limited to 170 and $70 \mathrm{mg} / \mathrm{L}$, respectively. Besides, the overall efficiency of ABR has not been changed significantly in a range of 36-18 h HRT. Consequently, it is found that ABR as an efficient, economical and environmentally sound option can be considered as a sustainable alternative to upgrade WSPs operationally.
\end{abstract}

Keywords: Anaerobic baffled reactor (ABR), purple sulfur bacteria, stabilization pond, upgrade, wastewater treatment.

\section{INTRODUCTION}

Since stabilization ponds treating domestic wastewater are operated efficiently, they would be introduced as a sustainable unit especially in tropical and subtropical regions. Also, little required technology makes them an appropriate method for developing countries like Iran where sufficient land and sunlight intensify their popularity [1-5]. Yet, reliable and efficient operation is considerably dependant on a wide range of environmental conditions. These variations may have impact on different parts of the system [6, 7].

Typically, wastewater stabilization ponds (WSPs) are made of two indispensable parts in sequence. First, anaerobic pond (AP) can play a key role in reducing organic loads as well as equalizing influent for the following ponds. These units are open and the whole gas generated such as methane, carbon dioxide, and hydrogen can be emitted freely to the atmosphere $[8,9]$. Second, the specific aerobic-anaerobic culture can be dominated in facultative pond rallied to organic matter decomposition $[2,4,6]$. The treatment process is formed by the complex symbiosis of different types of bacteria and algae species. The abundance and activity of these groups of micro-organisms would be influenced by periodic changes in $\mathrm{pH}$, organic loads, temperature, and light intensity [10, 11].

Among a variety of species, purple sulfur bacteria (PSB) are recognized to be prevalent in ponds which are colored red [12-17]. They represent a physiological group of unicellular, heterotrophic 
and autotrophic, Gram-negative bacteria phylogenetically classified as Gammaproteobacteria within the order Chromatiales $[18,19]$. They are ubiquitously distributed but restricted to aquatic habitats characterized by adequate light conditions, low oxygen tension, and moderate sulfide concentrations. The most characteristic feature of all PSBs is their ability to perform photosynthesis under anoxic condition in stagnant water, mainly using reduced sulfur compounds such as $\mathrm{H}_{2} \mathrm{~S}$ or thiosulfate as electron donors [20,21].

The presence of PSB in APs is beneficial for several reasons. First, by utilizing hydrogen sulfide as an electron donor for photosynthesis, these bacteria remove the principal cause of odor nuisances. Second, an important role in removal of biochemical oxygen demand (BOD) has been attributed to the PSBs [13]. Nevertheless, their abundance would deteriorate the symbiosis of living beings from algae to bacteria. It is found that the increasing of organic loads would reduce the number of green algae and increase the PSBs [2, 14, 22]. Recently, a case study has been carried out over a WSP in Hoveizeh city, Iran [2]. According to the results, the treatment facility is reported to be widely encountered with PSB bloom in the facultative ponds. This trait is recognized to be attributed to the high organic loading rate incoming to the treatment plant [2].

A variety of solutions could be made to modify and upgrade WSPs $[6,22,23]$ but few strategies have been examined to control the high organic loading rates [23]. Anaerobic baffled reactor (ABR) has been proved as a sustainable approach in domestic wastewater treatment [24-26]. It is successfully used as a pretreatment for duckweed ponds and wetlands treating wastewater as well [27, 28]. Recently, it is shown that the influent variations can be controlled and equalized efficiently within ABR compartments [29]. Besides, its configurations have been optimized by artificial neural network [30].

$\mathrm{ABR}$ is a hydraulically based unit that forces raw wastewater to be flown within its compartments mostly upward and have contact with the settled biomass theoretically. Also, the microbial groups can be partially separated in chambers [24, 31]. Hence, initial compartments are mostly constituted of acidogens while strict anaerobes are normally located in final parts [24, 31]. It means that the volatile fatty acids (VFAs) are expected to be produced in initial steps while they are gradually digested longitudinally down the reactor [30]. The finest configuration is recommended to be considered to prohibit VFAs to be accumulated. Moreover, the variations of hydraulic retention time (HRT) or influent COD can be neutralized with a reliable design [29, 30].

Regarding to the literatures and results of the case study (Hoveizeh), it has been proposed to assess the efficiency of ABR, as a pretreatment unit of the facultative ponds, in bench scale. This study is aimed to find out whether this modification is able to remove or control the origin of the problem. For this purpose, to have a comprehensive view and be able to achieve a genuine conclusion, at first, the case study is carried on in details as a supplementary research of the recent study. This would assist to identify the main causes and their relations involved in the problem. Then, it is followed by the pilot study, focusing on an assessment over the capability of using ABR to manage the adverse effects of high organic loads and neutralize the effective causes.

\section{MATERIALS AND METHODS}

\subsection{Site specifications}

The stabilization pond had been constructed to treat domestic wastewater in Hoveizeh city $\left(48^{\circ} \mathrm{N}\right.$, $31^{\circ} \mathrm{E}$ ) for the equivalent and final population of 9000 and 21,000 people, respectively (for 25 years). The place has a relatively hot and sultry climate with maximum temperature rises up to $51^{\circ} \mathrm{C}$ in summer. Also, the average precipitation is around $7 \mathrm{~mm} /$ year and the annual relatively humidity is $59.3 \%$ [2]. 
The waste stabilization pond comprised two APs in parallel followed by one facultative pond divided in three sequential divisions (Fig. 1). In Table 1, the efficiency of each unit in COD removal is summarized in details, whereas the physical and operational characteristics of the WSP units are presented in Table 2 [2].

\subsection{Pilot specifications and operational procedure}

In this study, to assess the possibility of using ABR as a modification for WSPs, a pilot study with similar characteristics to the previous studies is used [30]. It has been made of plexiglass with six compartments having net and total volume of 48 and 601 , respectively. The overall dimensions of length, width and height of the reactor are 90,15 and $50 \mathrm{~cm}$, and the volume ratio of upflow to downflow divisions of the compartments is considered as three to one. Also, the first and the sixth (final) compartments have been chosen to be as twice as other compartments in volume to allocate more control over suspended solids (Fig. 2) [32].

In order to start up, the pilot was inoculated with the activated sludge having an average concentration of $8000 \mathrm{mg} / \mathrm{L}$. Then, it has been fed with screened domestic wastewater pumped to the

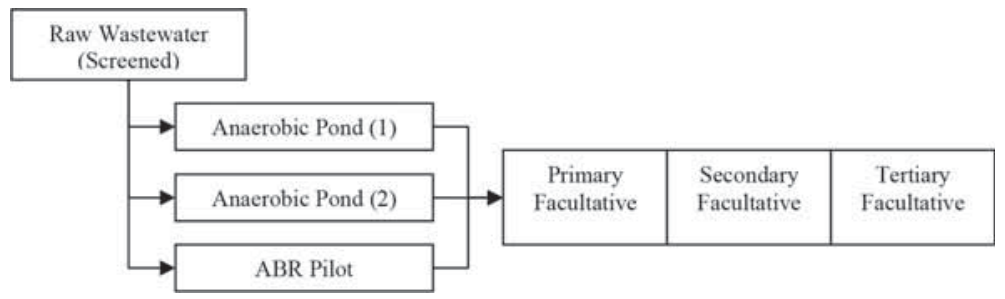

Figure 1: The schematic plot of the site.

Table 1: The average of the parameters in the WSP of Hoveizeh.

\begin{tabular}{lccccc}
\hline Units & $\begin{array}{c}\mathrm{SCOD}_{\text {in }} \\
(\mathrm{mg} / \mathrm{L})\end{array}$ & $\begin{array}{c}\mathrm{SCOD}_{\text {out }} \\
(\mathrm{mg} / \mathrm{L})\end{array}$ & $\begin{array}{c}\text { \% SCOD } \\
\text { removal }\end{array}$ & $\begin{array}{c}\mathrm{SCOD}_{\text {in }} / \mathrm{TCOD}_{\text {in }} \\
(\mathrm{mg} / \mathrm{L})\end{array}$ & $\begin{array}{c}\mathrm{SCOD}_{\text {out }} / \mathrm{TCOD}_{\text {out }} \\
(\mathrm{mg} / \mathrm{L})\end{array}$ \\
\hline $\begin{array}{l}\text { Anaerobic } \\
\text { ponds }\end{array}$ & $600 \pm 150$ & $330 \pm 112$ & $45 \pm 7$ & $0.4 \pm 0.06$ & $0.51 \pm 0.11$ \\
$\begin{array}{l}\text { Primary } \\
\text { facultative } \\
\text { pond }\end{array}$ & $330 \pm 112$ & $230 \pm 29$ & $30 \pm 11$ & $0.51 \pm 0.11$ & $0.36 \pm 0.04$ \\
$\begin{array}{l}\text { Secondary } \\
\text { facultative } \\
\text { pond }\end{array}$ & $230 \pm 29$ & $170 \pm 14$ & $26 \pm 4$ & $0.36 \pm 0.04$ & $0.34 \pm 0.03$ \\
$\begin{array}{l}\text { Tertiary } \\
\text { facultative } \\
\text { pond }\end{array}$ & $170 \pm 14$ & $168 \pm 15$ & $1.2 \pm 2$ & $0.34 \pm 0.03$ & $0.32 \pm 0.06$ \\
\hline
\end{tabular}

SCOD, soluble/filtered chemical oxidation demand; TCOD, total chemical oxidation demand (also known as COD). 
Table 2: Physical and operational characteristics of the WSP system [2].

\begin{tabular}{lcccc}
\hline Unit & $\begin{array}{c}\text { Area } \\
\left(\mathrm{m}^{2}\right)\end{array}$ & $\begin{array}{c}\text { Net volume } \\
\left(\mathrm{m}^{3}\right)\end{array}$ & $\begin{array}{c}\text { HRT } \\
(\text { days })\end{array}$ & $\begin{array}{c}\text { OLR (kg COD/m } \\
\text { day) }\end{array}$ \\
\hline Anaerobic pond 1 (AP1) & 1100 & 2700 & 2.4 & 0.63 \\
Anaerobic pond 2 (AP2) & 1100 & 2700 & 2.4 & 0.63 \\
Primary facultative pond (PFP) & 4200 & 10,500 & 4.7 & 0.14 \\
Secondary facultative pond (SFP) & 4200 & 10,500 & 4.7 & 0.14 \\
Tertiary facultative pond (TFP) & 4200 & 10,500 & 4.7 & 0.11 \\
\hline
\end{tabular}

HRT, hydraulic retention time (daily treated flow: $\left.2250 \mathrm{~m}^{3}\right)$; OLR, organic loading rate $\left(\mathrm{COD}_{\text {in }} / \mathrm{HRT}\right)$.

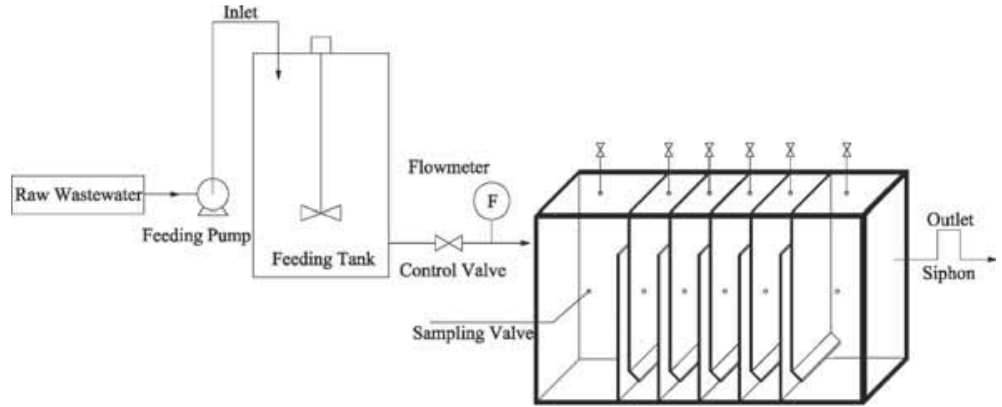

Figure 2: Schematic plot of the ABR pilot.

feeding tank where pressure head and flowrate were fixed by floaters and valves [30]. As the influent concentration of soluble COD was approximately $600 \mathrm{mg} / \mathrm{L}$, the flow was kept low till HRT be remained about $50 \mathrm{~h}$ in startup period for a month $[29,30]$. Then, the HRT is reduced gradually to 36,24 and $18 \mathrm{~h}$ each for 2 months operation. The whole of pilot study has been performed from November 2011 to June 2012 while are followed after the case studies in 2011.

\subsection{Sampling and tests}

In this study, the parameters of COD, chlorophyll A, hydrogen sulfide, $\mathrm{pH}$, and VFAs (i.e. acetate and propionate) were tested based on standard methods [33]. Volatiles were measured by gas chromatography flame ionization detector while the tests of chlorophyll were carried out by spectrophotometry method in $520 \mathrm{~nm}$ wavelength [34]. All the samplings have been performed under steady states in relevant locations. The data are reported monthly average and the analyses were taken 30 min utmost to be implemented [30].

\section{RESULTS AND DISCUSSIONS}

\subsection{Case study}

As implied in Section 2.1, the concentrations of soluble and total COD of raw wastewater with around 600 and $1500 \mathrm{mg} / \mathrm{L}$ have been reported to be much higher than the assumed design criteria 
of 250 and $550 \mathrm{mg} / \mathrm{L}$, respectively. It means that if the efficiency of AP is considered to be $45 \%$ (Table 1), the surface loading rate of the primary facultative pond (PFP) would be around $1200 \mathrm{~kg}$ $\mathrm{BOD} /$ ha day while it is recommended to be maintained below $350[4,6,35,36]$. Hence, this system is known to be encountered with high organic loads [2,35].

In wastewater treatment, high organic load would have influence on biological relations $[29,30$, $37,38]$. With regard to the results, it can be revealed that the high COD level can have impact on the concentration of the soluble hydrogen sulfide. This is shown in Fig. 3, originated by experimental samples obtained from the effluent of the AP $\left(\mathrm{H}_{2} \mathrm{~S}\right)$ and incoming load (COD). This figure demonstrates that, in this case, the correlation of these two factors can well be matched statistically as a logarithmic phase $\left(\mathrm{R}^{2}=0.9\right)$. This is probably attributed to the inefficient performance of the anaerobic section.

In order to justify how the high organic load might affect $\mathrm{H}_{2} \mathrm{~S}$ concentration, the process should be reviewed. The soluble COD represents readily biodegradable organics which is aimed primarily to be removed in wastewater treatment [35]. With regard to Table 1, the average ratio of the soluble to total COD is increased from 0.4 to 0.51 in the APs. This is probably due to imperfect anaerobic process $[26,30,37,38]$.

The procedure of degrading organics in anaerobic systems is consisted of two main parts [35]. First, acidogenesis heterotrophic bacteria hydrolyze organics to readily biodegradable and soluble VFAs known as byproducts (i.e. acetate and propionate). Then, methanogens which play a key role in anaerobic process compete with other species such as sulfate reducing bacteria (SRBs) to use these materials to produce gas (Table 3). Since the performance of the second group has not been interfered with adverse operational conditions, the ratio of the soluble to total COD would be decreased in time. Otherwise, it is increased by means of releasing undigested soluble byproducts $[39,40]$. Accordingly, through an unbalanced anaerobic process as pretreatment, VFAs would be transferred to the facultative ponds in higher concentrations. These circumstances assist the presence of PSBs and their growth to be expedited through three ways [2, 20, 21]. (1) VFAs, as readily

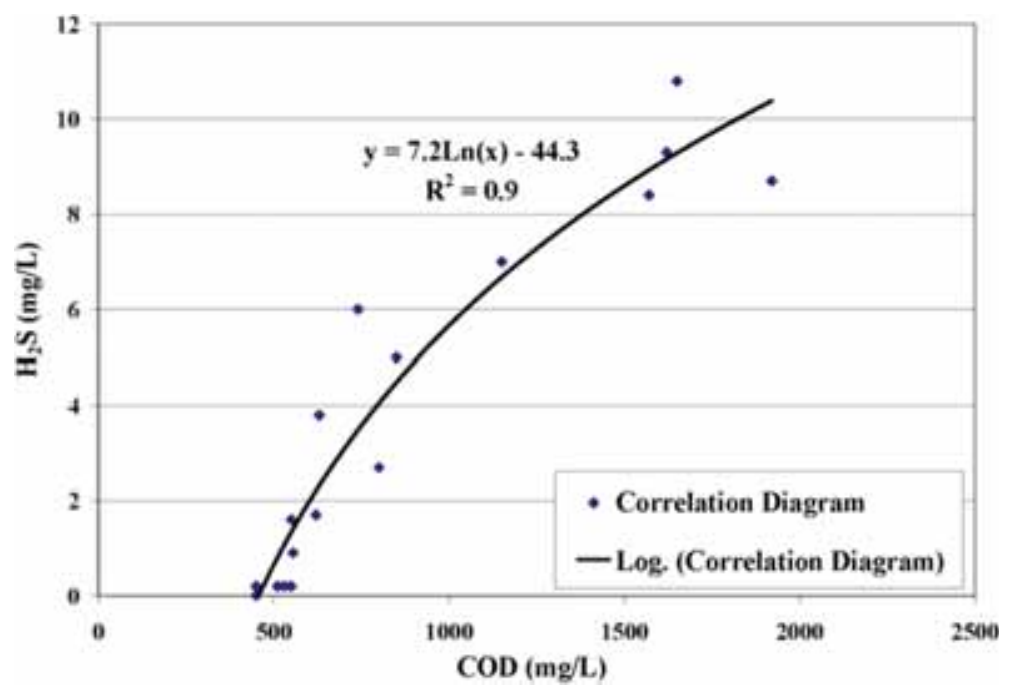

Figure 3: The correlation diagram of the $\mathrm{COD}$ and $\mathrm{H}_{2} \mathrm{~S}$ in the influent and effluent of the anaerobic pond (AP), respectively. 
Table 3: Relevant reactions attributed to biological or chemical factors [35].

\begin{tabular}{ll}
\hline Reaction & Attributed to \\
\hline $\mathrm{C}_{6} \mathrm{H}_{12} \mathrm{O}_{6} \rightarrow 3 \mathrm{CH}_{3} \mathrm{COOH} \leftrightarrow 3 \mathrm{CH}_{3} \mathrm{COO}^{-}+3 \mathrm{H}^{+}$ & Heterotrophic acidogens \\
$\mathrm{CH}_{3} \mathrm{COOH} \rightarrow \mathrm{CH}_{4}+\mathrm{CO}_{2}$ & Heterotrophic methanogens \\
$\mathrm{CO}_{2}+4 \mathrm{H}_{2} \rightarrow \mathrm{CH}_{3} \mathrm{COOH}+2 \mathrm{H}_{2} \mathrm{O}$ & Autotrophic methanogens \\
$\mathrm{SO}_{4}{ }^{2-}+\mathrm{CH}_{3} \mathrm{COOH}+2 \mathrm{H}^{+} \rightarrow \mathrm{HS}^{-}+2 \mathrm{HCO}_{3}{ }^{-}+3 \mathrm{H}^{+}$ & Sulfate reducing bacteria \\
$\mathrm{CO}_{2}+2 \mathrm{H}_{2} \mathrm{O} \rightarrow \mathrm{CH}_{2} \mathrm{O}+\mathrm{H}_{2} \mathrm{O}+\mathrm{O}_{2}$ & Photosynthesis \\
$\mathrm{H}_{2} \mathrm{~S} \leftrightarrow \mathrm{HS}^{-}+\mathrm{H}^{+} \leftrightarrow \mathrm{S}^{2-}+2 \mathrm{H}^{+}$ & pH impact on $\mathrm{H}_{2} \mathrm{~S}$ \\
$\mathrm{Fe}^{+2}+\mathrm{S}^{2-} \rightarrow \mathrm{FeS}(\mathrm{S})$ & Sulfur precipitation by iron \\
\hline
\end{tabular}

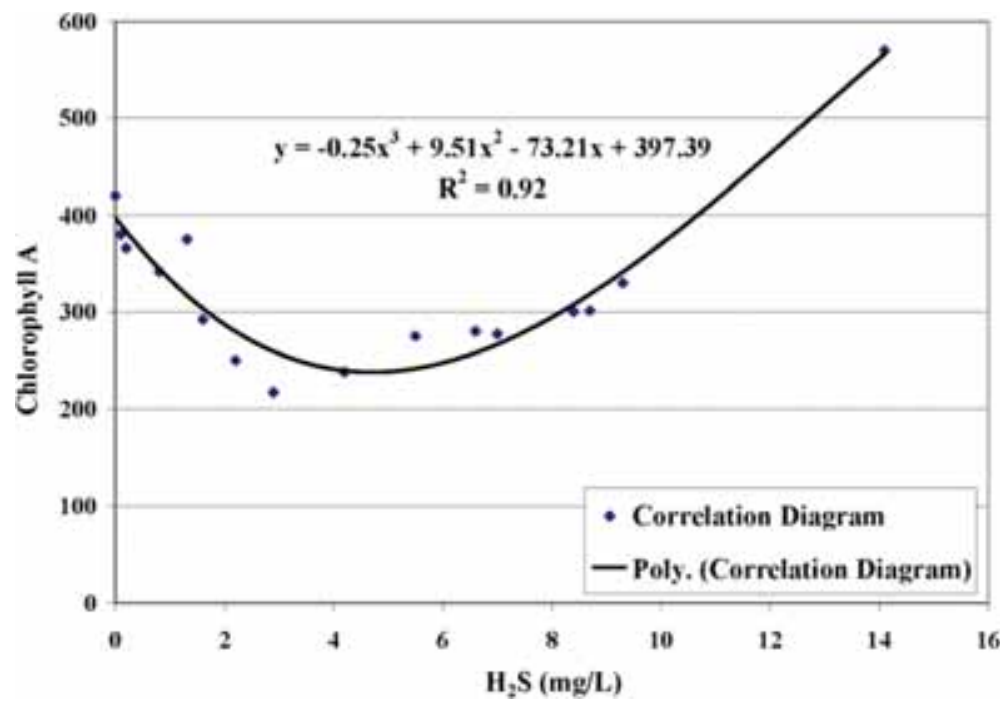

Figure 4: The correlation of $\mathrm{H}_{2} \mathrm{~S}$ and chlorophyll (A) in the primary facultative pond (PFP).

biodegradable and favorable feed, can well be consumed by PSBs, and (2) the ratio of the concentration of VFAs to alkalinity would be reduced and the $\mathrm{pH}$ level can be influenced significantly. This phenomenon provides not only an unstable condition for methanogens $[39,40]$ but also a proper state for dissolving more hydrogen sulfide $\left(\mathrm{H}_{2} \mathrm{~S}\right)$ (Table 3), (3) the biological process of the facultative pond would be enforced by low dissolved oxygen as a result of high COD level. Thus, the anoxic condition can be supported to be dominated [2, 20,21]. Since photosynthetic PSBs are dependent on the anoxic condition, carbon source and most of all, hydrogen sulfide; they were unfavorably dominated in the ponds ahead. By this fact, the amount of SCOD reported to be removed to $30 \%$ in the facultative pond can be attributed to the PSBs (Table 1).

To show how the growth of PSBs might be related to the $\mathrm{H}_{2} \mathrm{~S}$ concentration and influent COD as well, the amount of chlorophyll (A) as an index of PSBs is tested [20] and the relevant data are plotted in Fig. 4. With regard to the samples obtained from the influent and effluent of the PFP, it is revealed that $\mathrm{H}_{2} \mathrm{~S}$ concentration and chlorophyll $(\mathrm{A})$ are correlated as a third-order equation $\left(\mathrm{R}^{2}=0.92\right)$.

In this diagram, the first phase that shows a reduction in chlorophyll can probably be due to low VFAs or carbon dioxide $\left(\mathrm{CO}_{2}\right)$ concentrations. These two materials are accounted as the feeds of 
SRBs or heterotrophic methanogens and autotrophic methanogens, respectively [39, 40]. As organic load (or COD) is increased in raw wastewater, the concentration of these substances would be expected to be raised directly in the anaerobic process [30]. Primarily, the groups of bacteria mentioned above might try to consume VFAs in competence with PSBs [39]. Eventually, $\mathrm{H}_{2} \mathrm{~S}$ concentration is developed while the growth of algae is inhibited. As the accumulation of VFAs is exceeded the demands of other species, the growth of PSBs can be increased [35].

With regard to Figs 3 and 4, it can be concluded that the substrate of PSBs has been limited by the effluent of the AP till organic load exceeds 850 to $900 \mathrm{mg} / \mathrm{L}$ of total COD (Fig. 3). Therefore, $\mathrm{H}_{2} \mathrm{~S}$ concentration can be increased to $4.5 \mathrm{mg} / \mathrm{L}$ and the trend of diagram is changed to upward thereafter (Fig. 4). This is happened through accumulation of VFAs in AP mainly [23, 39]. Hence, to prevent the ponds be colored red, it can be recommended to maintain the COD concentration of the influent to $<850 \mathrm{mg} / \mathrm{L}$ (soluble COD to $<400 \mathrm{mg} / \mathrm{L}$ ) as an operational limit. Otherwise, it is highly recommended to upgrade the AP and use more reliable and efficient units. Consequently, the application of ABR with six compartments has been examined in bench scale to assess its performance especially with emphasize on controlling the concentration of VFAs as the key parameter.

\subsection{Pilot study (ABR)}

In this step, it is focused on the efficiency of ABR especially on removing VFAs, because they were recognized as the limiting parameter of PSBs growth. As a result, ABR is shown to be capable of limiting VFAs concentration in the effluent to $<70 \mathrm{mg} / \mathrm{L}$. In comparison, it was observed that the conventional APs had an average VFAs concentration of $190 \mathrm{mg} / \mathrm{L}$. The former is able to keep the ratio of VFAs to alkalinity about 0.23 , whereas the latter has a ratio of about 0.63 . Thus, the $\mathrm{pH}$ level of the effluent of ABR could be remained on an average of 7.2.

Furthermore, ABR has shown to be able to reduce the SCOD about $70-73 \%$, which is $25 \%$ more than the average efficiency of conventional APs (45\%). This would lead into lower COD emission to the facultative pond ahead. It means that the influent COD of PFP would be reduced from $330 \mathrm{mg} / \mathrm{L}$ (with AP) to $170 \mathrm{mg} / \mathrm{L}$ (with $\mathrm{ABR}$ ), whereas the surface loading rate would be reduced down to around $450 \mathrm{~kg}$ BOD/ha day. This could be achieved if ABR with $24 \mathrm{~h}$ retention time is used. Obviously, lower organics transferred to the facultative pond would reduce the requirement of dissolved oxygen (Table 3), and the possibility of aerobic phase would be promoted [35]. The concentrations of VFAs and soluble COD of ABR in three different HRTs and in comparison with the AP are illustrated in Fig. 5.

With regard to the results, it can be concluded that ABR with six compartments and 24-h retention time, which is 2.25 times less than APs, can be introduced as a proper alternative to upgrade the conventional system. By degrading higher amounts of organic substrates, controlling VFAs emission, reducing oxygen demand in further units, and balancing the $\mathrm{pH}$ level, the growth of PSBs could be expected to be inhibited. Moreover, if a variation in flow occurs and HRT is forcefully reduced to $18 \mathrm{~h}$, still the system is named to be reliable and would not be deteriorated likewise the reports of previous literatures $[29,37]$. This is known as about $30 \%$ safety factor. Besides, by covering the head of anaerobic system as it is custom, the generated biogas can be gathered and reused [24, 35].

Meanwhile, still there are other factors such as hydrogen sulfide to be considered. To make sure about inhibition of transferring $\mathrm{H}_{2} \mathrm{~S}$ to the further units, it can be recommended that (1) the gas produced should be burnt to keep its pressure low within the system [38], (2) ferrous additives should be used to make sulfide be settled [41], or (3) iron electrodes for electro-coagulation can be used in final compartment of ABR to reduce not only the sulfide concentration but also the suspended solids coming out. The latter assists the turbidity to be declined and green algae could be well supported by 


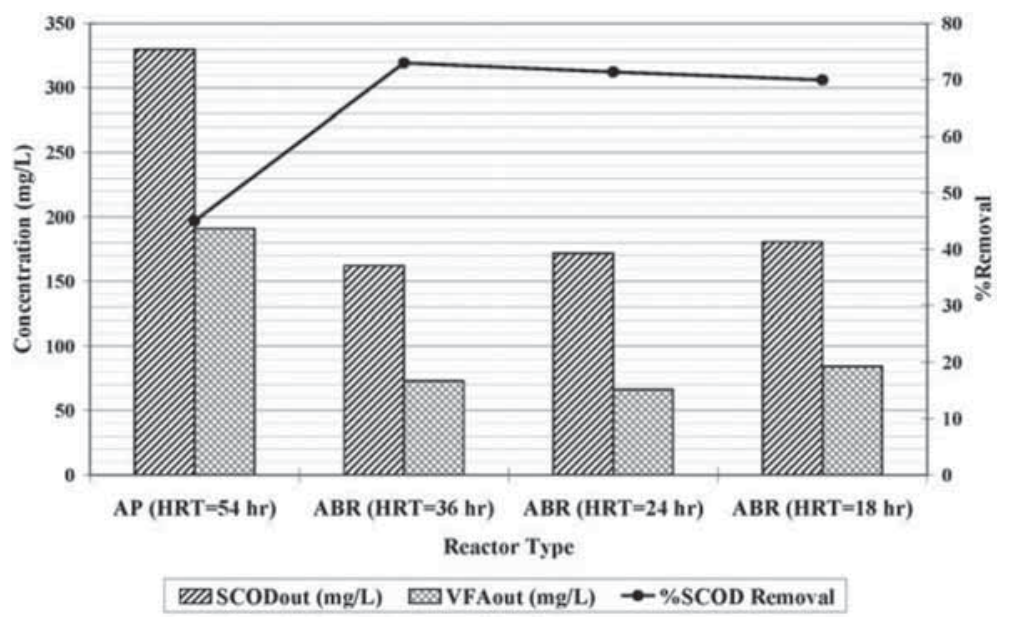

Figure 5: The comparison of the effluent of anaerobic pond (AP) and ABR.

sunlight in the facultative ponds $[9,13,39]$. This technology is successfully tested in laboratory studies recently to upgrade ABR as a pretreatment unit [42] but required more studies in larger scales.

With regard to the discussions above, it can be summarized that ABR with six compartments, 24-h retention time and equipped with biogas gathering system or conductive electrodes like iron in effluent can be introduced as a modification for conventional APs which would control high organic loads and inhibit PSB growth. It should be noted that still there are questions to be answered about its performance in full scale or for a long-time operational period.

\section{CONCLUSION}

This study is focused on evaluating the causes of PSB bloom and finding a sustainable solution in WSP of Hoveizeh, Iran. Based on the results of the case study, it is realized that the high organic loading rate is responsible for the operational failure. This is substantiated by the experimental data and relations unfolded among chlorophyll $\mathrm{A}, \mathrm{H}_{2} \mathrm{~S}$, COD, and VFAs concentrations.

As a solution, it is recommended to use ABR which is able to either keep the concentration of VFAs down or have a high efficiency on COD removal. Both are assessed and confirmed in the bench-scale pilot that has shown a reliable application even in different hydraulic retention times. In a word, it can be concluded that the efficiency of ABR as a pretreatment unit of wastewater facultative ponds is confirmed by the experimental results, and it can be recommended as an upgrading alternative of the conventional APs that are operationally failed particularly as a consequence of high influent organic load.

\section{REFERENCES}

[1] Hamdy, A., Rabia, N. \& Hamdy, S., Study of waste stabilization pond geometry for wastewater treatment efficiency. Ecological Engineering, 28, pp. 25-34, 2006. doi: http://dx.doi. org/10.1016/j.ecoleng.2006.03.008

[2] Jamshidi, Sh., Badalians Gholikandi, G. \& Orumieh, H.R., High organic loading rate and waste stabilization pond's operation efficiency: a case study, Proc. of the 3rd Int. Conf. of Natural Resources, Sustainable Development and Ecological Hazards, Ravage of the Planet III, eds. C.A. Brebbia, S.S. Zubir, Shah Alam, Malaysia, WIT Press, pp. 415-424, 2011. 
[3] Kaya, D., Dilek, F. \& Gokcay C.F., Reuse of lagoon effluents in agriculture by post-treatment in a step feed dual treatment process. Desalination, 215, pp. 29-36, 2007. doi: http://dx.doi. org/10.1016/j.desal.2006.11.013

[4] Mara, D.D., Domestic Wastewater Treatment in Developing Countries, Earthscan Publications: London, 2004.

[5] Nelson, K.L., Cisneros, B.J., Tchobanoglous, G. \& Darby, J., Sludge accumulation, characteristics, and pathogen inactivation in four primary waste stabilization ponds in central Mexico. Water Research, 38, pp. 111-127, 2004. doi: http://dx.doi.org/10.1016/j.watres.2003.09.013

[6] Ashworth, J. \& Skinner, M., Waste stabilisation pond, design manual. Power and Water Corporation, Document No: D2011/578598, pp. 40-55, December 2011.

[7] Lloyd, B.J., Leitner, A.R., Vorkas, C.A. \& Guganesharajah, R.K., Under performance evaluation and rehabilitation strategy for waste stabilization ponds in Mexico. Water Science and Technology, 48(2), pp. 35-43, 2003.

[8] Park, J.B.K. \& Craggs, R.G., Biogas production from anaerobic waste stabilization ponds treating dairy and piggery in New Zealand. Water Science and Technology, 55(11), pp. 257-264, 2007. doi: http://dx.doi.org/10.2166/wst.2007.357

[9] Picot, B., Paing, J., Sambuco, J.P., Costa, R.H.R. \& Rambaud, A., Biogas production, sludge accumulation and mass balance of carbon in anaerobic ponds. Water Science and Technology, 48(2), pp. 243-250, 2003.

[10] Kayombo, S., Mbwette, T.S.A., Mayo, A.W., Katima, J.H.Y. \& Jorgrnsen, S.E., Diurnal cycles of variation of physical-chemical parameters in waste stabilization ponds. Ecological Engineering, 18, pp. 287-291, 2002. doi: http://dx.doi.org/10.1016/S0925-8574(01)00086-6

[11] Murakani, K., Inomari, Y., Sudo, R. \& Kurihara, Y., Effect of temperature on prosperity and decay of genetically engineered micro-organisms in a microcosm system. Water Science and Technology, 26 (9-11), pp. 2165-2165, 1992.

[12] Alabaster, G.P., Combined treatment of domestic and industrial wastewater stabilization pond systems in Kenya. Water Science and Technology, 24, pp. 43-52, 1991.

[13] Freedman, D., Koopman, B. \& Lincoln, E.P., Chemical and biological flocculation of purple sulphur bacteria in anaerobic lagoon effluent. Journal of Agricultural Engineering Research, 28, pp. 115-125, 1983. doi: http://dx.doi.org/10.1016/0021-8634(83)90081-1

[14] Houghton, S.R. \& Mara, D.D., The effects of sulfide generation in waste stabilization ponds on photosynthetic populations and effluent quality. Water Science and Technology, 26, pp. 1759-1768, 1992.

[15] Sirianuntapiboon, S. \& Srikul, M., Reducing red color intensity of seafood wastewater in facultative pond. Bioresource Technology, 97, pp. 1612-1617, 2006. doi: http://dx.doi. org/10.1016/j.biortech.2005.07.022

[16] Veenstra, S., Al-Nozaily, F.A. \& Alaerts, G.J., Purple non-sulfur bacteria and their influence on waste stabilisation pond performance in the Yemen Republic. Water Science and Technology, 31, pp. 141-149, 1995. doi: http://dx.doi.org/10.1016/0273-1223(95)00501-D

[17] Villanueva, J., Grimalt, J.O., Wit, R.D., Brendan, J.K. \& Maxwell, J.R., Sources and transformations of chlorophylls and carotenoids in a monomictic sulphate-rich karstic lake environment. Organic Geochemistry, 22, pp. 739-757, 1994. doi: http://dx.doi.org/10.1016/01466380(94)90136-8

[18] Angelica, P.S., Tommy, H. \& Overmann, J., Physiology of purple sulfur bacteria forming macroscopic aggregates in great sippewissett salt marsh, Massachusetts. FEMS Microbiology Ecology, 12, pp. 225-235, 1993. doi: http://dx.doi.org/10.1111/j.1574-6941.1993.tb00035.x 
[19] Imhoff, J.F., Order I. Chromatiales ord. nov. Bergey's Manual of Systematic Bacteriology, Springer: New York, 2005.

[20] Guyoneaud, R., Wit, R.D., Matheron, R. \& Caumette, P., Impact of macroalgal dredging on dystrophic crises and phototrophic bacterial blooms (red waters) in a brackish coastal lagoon. Oceanologica Acta, 21, pp. 551-561, 1998. doi: http://dx.doi.org/10.1016/S03991784(98)80038-8

[21] Tank, M., Thiel, V. \& Imhoff, J.F., Phylogenetic relationship of phototrophic purple sulfur bacteria according to pufL and pufM gens. International Microbiology, 12, pp. 175-185, 2009.

[22] Pearson, H.W., Mara, D.D. \& Bartone, C.R., Guidelines for the minimum evaluation of the performance of full-scale waste stabilization ponds. Water Research, 21(9), pp. 1067-1075, 1987. doi: http://dx.doi.org/10.1016/0043-1354(87)90028-5

[23] Peña, M.R., Advanced Primary Treatment of Domestic Wastewater in Tropical Countries: Development of High-rate Anaerobic Ponds, PhD Thesis, School of Civil Engineering, University of Leeds, 2002.

[24] Barber, W.P. \& Stuckey D.C., The use of the anaerobic baffled reactor (ABR) for wastewater treatment: a review. Water Research, 33(7), pp. 1559-1578, 1999. doi: http://dx.doi. org/10.1016/S0043-1354(98)00371-6

[25] Feng, H., Hu, L., Shan, D., Fang, C., He, Y. \& Shen, D., Effects of operational factors on soluble microbial products in a carrier anaerobic baffled reactor treating dilute wastewater. Journal of Environmental Sciences, 20, pp. 690-695, 2008. doi: http://dx.doi.org/10.1016/ S1001-0742(08)62114-2

[26] Krishna, G.V.T.G., Kumar, P. \& Kumar, P., Treatment of low strength soluble wastewater using an anaerobic baffled reactor (ABR). Journal of Environmental Management, 90, pp. 166-176, 2009. doi: http://dx.doi.org/10.1016/j.jenvman.2007.08.017

[27] Nasr, F.A., Doma, H.S. \& Nassar, H.F., Treatment of domestic wastewater using an anaerobic baffled reactor followed by a duckweed pond for agricultural purposes. Journal of Environmentalist, 29, pp. 270-279, 2009.

[28] Singh, S., Haberl, R., Moog, O., Raj Shrestha, R., Shrestha, P. \& Shrestha, R., Performance of anaerobic baffled reactor and hybrid constructed wetland treating high-strength wastewater in Nepal-A model for DEWATS. Journal of Ecological Engineering, 35, pp. 654-660, 2009. doi: http://dx.doi.org/10.1016/j.ecoleng.2008.10.019

[29] Badalians Gholikandi, G., Jamshidi, Sh. \& Ebrahimzade, V., The response of anaerobic baffled reactor in various operational conditions. International Journal of Wastewater Treatment and Green Chemistry, 2(1), pp. 1-10, 2011.

[30] Badalians Gholikandi, G., Jamshidi, Sh. \& Hazrati, H., Optimization of anaerobic baffled reactor (ABR) wastewater treatment system using artificial neural network. Environmental Engineering and Management Journal, 2012, in press.

[31] Nachaiyasit, S. \& Stuckey, D.C., Microbial response to environmental changes in an anaerobic baffled reactor (ABR). Antonie Van Leeuwenhoek, 65, pp. 111-123, 1995. doi: http://dx.doi. org/10.1007/BF00872199

[32] Dama, P., Bell, J., Brouckaert, C.J., Buckley, C.A. \& Stuckey, D.C., Computational fluid dynamics: application to the design of the anaerobic baffled reactor, Proceedings of WISA Biennial Conference, Sun City, South Africa, 2000.

[33] APHA, Standard Methods for the Examination of Water and Wastewater, 24th edn. American Public Health Association: Washington, DC, 2005.

[34] Matsuyama, M., Phylogenic status of a purple sulfur bacterium and its bloom in Lake Kaiike. The Japanese Society of Limnology, 5, pp. 95-101, 2004. 
[35] Tchobanoglous, G. \& Burton, F.L., Wastewater Engineering: Treatment, Disposal and Reuse, McGraw Hill: New York, 2003.

[36] USEPA, Design Manual for Municipal Wastewater Stabilization Ponds, NSCEP, 1983.

[37] Langenhoff, A., Intrachandra, N. \& Stuckey, D.C., Treatment of dilute soluble and colloidal wastewater using an anaerobic baffled reactor: influence of hydraulic retention time. Water Research, 34(4), pp. 1307-1317, 2000. doi: http://dx.doi.org/10.1016/S0043-1354(99)00236-5

[38] Voolapalli, R.K. \& Stuckey, D.C., Hydrogen production in anaerobic reactors during shock loads-influence of formate production and $\mathrm{H}_{2}$ kinetics. Water Research, 35(7), pp. 1831-1841, 2001. doi: http://dx.doi.org/10.1016/S0043-1354(00)00441-3

[39] Gerardi, M.H., The Microbiology of Anaerobic Digesters, John Wiley \& Sons: Hoboken, New Jersey, 2003. doi: http://dx.doi.org/10.1002/0471468967

[40] Gerardi, M.H., Wastewater Bacteria, John Wiley \& Sons: Hoboken, New Jersey, 2006. doi: http://dx.doi.org/10.1002/0471979910

[41] Fu, F. \& Wang, Q., Removal of heavy metal ions from wastewaters: a review. Environmental Management, 92(3), pp. 407-418, 2011. doi: http://dx.doi.org/10.1016/j.jenvman.2010.11.011

[42] Badalians Gholikandi, G., Jamshidi, Sh. \& Valipour, A., Application of electrolysis upgrading the operation of anaerobic reactors, (in Persian). Journal of Environmental Studies, 38(4), pp. 9-16, 2013. 